HYDROLYSIS OF SYNTHETIC PHOSPHATIDES BY CLOSTRIDIUM WELCHII PHOSPHATIDASE ${ }^{1\}}$

I.I.M. van Deenen, G.H. de Haas, C.H.Th.Heemskerk and J.Meduski Laboratory of Organic Chemistry, University of Utrecht, The Netherlands.

Received February 1, 1961

After the finding of MacFarlane and Knight (1941) that the hemolytic factor of C.welchil a-toxin exhibits phosphatidase activity, various specificity characteristics of this enzyme (phosphatidase D) have been described (MacFarlane, 1948;

Zamecnik et al., 1947). As regards the ability of phosphatidase D to liberate phosphoryl choline from saturated lecithins, opinions appear to differ. Hanahan and Vercamer (1954) observed that in an ether-ethanol medium both a fully saturated and an unsaturated lecithin were completely hydrolysed, which fact was also found by Meduski et al. (1956) in an aqueous medium. on the other hand, Long and Maguire (1954) reported that in the latter medium saturated lecithins resisted phosphatidase $D$ action. In the course of an investigation into the susceptibility of red cells from different animal species against hemolytic agents, it appeared necessary to obtain additional information on the substrate specificity of phosphatidase $D$. Beside variations in the phosphatide composition we found the fatty acid pattern of glycoro-phosphatides from red cell membranes to vary greatly between various species of mamals (Kogl et al. 1960a). For this reason the action of phosphatidase $D$ was studied on $a$ series of synthetic lecithins carrying very different fatty

1) Contribution No.17 in the series: Metabolism and functions of phosphatides. 
acids. In addition some experiments were performed on synthetic phosphatidyl ethanolamines.

\section{MATERIALS AND NETHODS}

In the quantitative experiments use was made of a purified preparation of phosphatidase D, isolated by Meduski and Olkowska et al. (1958) from C.perfringens (strain SR 12). The results were qualitatively confirmed with a widely used C.welchii filtrate ( 300 MLD per $\mathrm{ml}$ ), generously supplied by Lederle Laboratories, Pearl River, N.Y. The synthesis of the lecithins has already been described (de Haas and van Deenen 1960a, 1960b; Kögl et al. 1960b). The "mixed-acid" cephalins were prepared fully synthetically according to a modification of the method developed for the synthesis of the corresponding lecithins (de Haas and van Deenen 1960a); I- $\alpha-[$ dioleoyl]phosphatidyl ethanolamine was prepared by $F$. Daemen using a method which will be published shortly. To $1 \mathrm{ml}$ of an $0,05 \mathrm{M}$ aqueous solution or emulsion of phosphatides (borate buffer $\mathrm{pH}=7,0 ;\left[\mathrm{Ca}^{++}\right]=0,0025$ M) was added $5 \mathrm{mg}$ of the bacterial toxin, and the mixture was subsequently incubated under gently shaking at $37^{\circ}$. Control experiments without toxin were carried out under identical conditions. After the desired incubation periods samples containing $15 \mu \mathrm{g}$ of phosphorus were withdrawn and the proportions of the formed phosphoryl choline and resulting phosphatides were determined after paper-chromatographical separation. Paper chromatograms were developed on Whatman paper No.1 with butanolethanol - water $(5: 5: 2 \mathrm{v} / \mathrm{v}$ ) as described before (Kögl et al. 1960b) and in the case of long-chain compounds on silica impregnated paper according to Marinetti et al. (1959). The spots were ashed directly with $70 \%$ perchloric acid and phosphorus 
determinations were carried out according to Hooghwinkel and van Niekerk $(1960)$.

\section{RESULTS}

The results (table I) demonstrated, in contrast to the observations of Kushner and Heimpel (1957) and of Long and Maguire (1954), that in a merely aqueous system pure lecithins are attacked by C.welchii phosphatidase and that both saturated and unsaturated compounds are hydrolysed. Within the class of the saturated lecithins the $\mathrm{C}_{10}$ homologue (IV) which gives stable dispersions in water, was readily converted. An increase of the chain length of the fatty acid, viz. $C_{12}$ (branched), $C_{15}, C_{18}$ and $\mathrm{C}_{24}$ homologues (V-VIII), brought about a significant decrease of the rate of hydrolysis. Since in the given sequence the possibility to prepare aqueous emulsions of these lecithins decreases, the observed effect is probably due to an inability of enzyme-substrate interaction, because of uneffective emulsifying of these lecithins (compare Hanahan 1957).

The short-chain $\mathrm{C}_{7}$ homologue (III) being rather watersoluble, was hydrolysed, which fact agrees with the observations of Roholt and Schlamowitz (1958) on $I-\alpha-$ (dicaproyl)-lecithin. Surprisingly, the readily water-soluble $\mathrm{C}_{4}$ and $\mathrm{C}_{2}$ compounds (II and I) resisted phosphatidase $D$ action. Two interpretations of this observation can be offered. According to the first it is presumed that the concerning rather water-soluble diglycerides are formed to a small extent and strongly inhibit the enzymatic reaction. The second interpretation implies that a minimal chain length of the fatty acids is required for the (interfacial) lecithin-enzyme interaction. These possibilities are being investigated. 
As expected, the lecithins IX and $X$, each carrying two mono unsaturated fatty acids, were readily attacked by the bacterial phosphatidase. The structural isomeric lecithins XI and XII, like many naturally occurring lecithins containing one saturated and one unsaturated fatty acid, were also hydrolysed.

Table I

Rate of hydrolysis of phosphatides in an aqueous medium by phosphatidase $D$ of $C$.perfringens

$\begin{array}{ll}\text { Sub s t r a t } s & \begin{array}{l}\text { Hydrolysis } \\ \text { \% after }\end{array} \\ & 1 \mathrm{~h} 3 \mathrm{~h} 22 \mathrm{~h}\end{array}$

Saturated lecithins

I $\quad L-\alpha-($ diacetyl $)$ Iecithin

$\begin{array}{lll}0 & 0 & 0\end{array}$

II $I-\alpha-($ dibutyryl)lecithin

III $L-\alpha-($ diheptanoyl)lecithin

$0 \quad 0<5$

IV $I-\alpha-($ didecanoyl) lecithin

$\begin{array}{lll}33 & 44 & 74\end{array}$

V I- $\alpha-\left(\alpha i-10-m e\right.$ thylundecanoyl)lecithin ${ }^{1)}$

$\begin{array}{lll}60 & 89 & 100\end{array}$

VI $I-\alpha-\left(\right.$ dipentadecanoyl)lecithin ${ }^{1)}$

$0 \quad 4 \quad 31$

VII $L-\alpha-($ distearoyl $)$ lecithin 1$)$

VIII $I-\alpha-$ (ditetracosanoyl)lecithin ${ }^{1)}$

$\begin{array}{lll}15 & 20 & 27\end{array}$

$0 \quad 0<10$

000

Unsaturated lecithins

IX $I-\alpha-(d i-$ undecenoyl)lecithin

$\begin{array}{lll}87 & 95 & 100\end{array}$

$X \quad I-\alpha-(d i-01 e o y 1)$ lecithin

$55100 \quad 100$

Mixed-acid lecithins

XI ( $\gamma$-stearoyl- $\beta$-oleoy 1$)-L-\alpha-1$ ecithin

$640 \quad 90$

XII ( $\gamma$-oleoyl- $\beta$-stearoyl)-I- $\alpha-$ lecithin

2550

Cephalins

XII $I-\alpha-(d i-o l e o y l p h o s p h a t i d y l)$ ethanolamine

XIV ( $\gamma$-stearoyl- $\beta-o l e o y l)-I-\alpha$-phosphatidylethanolamine

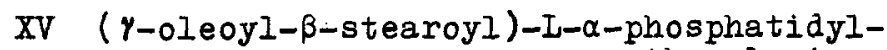
ethanolamine

1) The lecithins V, VI and VII were incompletely dispersed; VIII was not emulsifiable at all.

As regards the aotion of $C$.welchii phosphatidase on other 
types of phosphatides, Zamecnik et al. (1947) and MacFarlane (1948) did not observe a hydrolysis of natural cephalins. Chu (1949) obtained a similar result, but pointed out that B.cereus phosphatidase(s), acting upon lecithins like a phosphatidase $D$, could hydrolyse brain cephalins. This finding was confirmed by Robinson et al. (1957), who agreed with Chu that the occurrence of another phosphatidase in B.cereus filtrate is not precluded. Kushner and Feldman (1958), however, observed that both a C.perfringens and B.cereus toxin released phosphoryl ethanolamine from human brain thromboplastin. Our experiments with C.perfringens phosphatidase showed no detectable hydrolysis of three synthetic phosphatidyl ethanolarines (XIII-XV) under conditions allowing the degradation of the corresponding lecithins $(X-X I I)$. However, in current experiments we observed that cephalins present in red cell membranes were attacked by phosphatidase D. Details will be publisied shortly.

\section{REFERENCES}

Chu, H.P., J.Gen.Microbiol. 3, 255 (1949)

Haas, G.H. de, and Deenen, L.L.M. van, Tetrahedron Letters No.9, 1 (1960a); ibid. No.22, 7 (1960b)

Hanahan, D.J., Progress in Chemistry of Fats and other Lipids, Vol.4, Pergamon Press, Iondon 1957, p.141

Hanahan,'D.J., and Vercamer, R., J.Am.Chem.Soc. 76, 1804 (1954)

Hooghwinkel, G.J.M., and Niekerk, H.P.G.A. van, Proc.Acad.Sci. Amsterdam 63, 475 (1960)

K8gI, F., Gier, J. de, Mulder, I., and Deenen, I.I.M. van, Biochim.et Biophys.Acta 43,95 (1960a)

KÖgI, F. Haas, G.H. de, and Deenen, L.I.M. van, Rec.Trav.Chim. $79,661(1960 \mathrm{~b})$

Kushner, D.J., and Feldman, D., Biochim.et Biophys.Acta 30 , $466(1958)$

Kushner, D.J., and Heimpel, A.M., Can.J.Microbiol. 3 , 547 (1957)

Long, C., and Maguire, M.F., Biochem.J. 57, 223 (1954)

MacFarlane, M.G., Biochem.J. 42, 587 (1948)

MacFarlane, M.G., and Knight, B.C.J.G., Biochem.J. 35, 884 (1941)

Marinetti, G.V., Albrecht, M., Ford, T., and Stotz, E., Biochim.Biophys.Acta 36, 4'(1959)

Meduski, J., Zbrozyna, A., Zakrzewska, A., and Olkowska, D., Acta Micr.Polonica $\frac{5}{3}, 73(1956)$; Med.Dosk.Mikr. 10,247 (1958); ibid. 11, 135 (1958) 
Robinson, D.S., Harris, P.M., and Poole, J.C.F., Quart.J.Exptl. Physiol. 42, 285 (1957) Roholt, 0.A. and Schlamowitz, M., Arch.Biochem.Biophys. 77 ,

Zamecnik, P.C., Brewster, L.E., and Lipmann, F., J.Expt1.Med. 85, $381(1947)$ 